\title{
Screening of Superior Genotypes for Cold Tolerance and MYMV Resistance in Greengram (Vigna radiata)
}

\author{
M. Kabi ${ }^{1}$, T.R. Das $^{2^{*}}$ and B. Baisakh ${ }^{1}$ \\ ${ }^{1}$ Department of Plant Breeding and Genetics, OUAT, Bhubaneswar (Odisha) 751003, India \\ ${ }^{2}$ Indian Agriculture Research Institute (IARI) Regional station, Pusa (Bihar) 848125, India \\ *Corresponding author
}

\section{A B S T R A C T}

Greengram (Vigna radiata) is one of an important pulse crop grown as pre-rabi, rabi and summer crop in Odisha. During rabi season, the cold stress affect this crop and reduce its productivity. The genotypes with little winter hardiness will be beneficial to the

Keywords

Greengram, Cold tolerance, MYMV resistance.

\section{Article Info}

Accepted:

17 October 2017

Available Online:

10 December 2017 agroclimatic zone having rabi temperature around $15^{\circ} \mathrm{C}$. Therefore a study was under taken on twenty one genotypes along with nine check varieties in both laboratory and field condition at different location during the winter season. The genotypes OBGG-2013-9 and OBGG-2013-14 found best cold tolerant lines and can be used as donor for cold tolerance breeding. The genotype OBGG-2013-34 was the highest yielder genotype having medium tolerance to cold with moderate susceptibility reaction to MYMV and produced $23 \%$ more than the best check variety (TARM-1) followed by OBGG-2013-20 and OBGG-2013-11 which showed resistant to MYMV but lack of cold tolerance ability. The genotype OBGG-2013-8 was superior in cold tolerance as well as MYMV resistance but low yield than the best check. Thus hybridization between OBGG2013-34 and OBGG-2013-20 or OBGG-2013-11 was expected to produce superior genotype combining gene for cold tolerance and MYMV resistance with higher yield potential. These cold tolerance genotypes will be more beneficial to eastern part of India where greengram crop is grown during rabi season in rice fallow cropping system and very useful to eco-geographical area where winter is little late.

\section{Introduction}

Greengram (Vigna radiata $\mathrm{L}$. Wilczek) is one of the important short duration pulse crops of India and an excellent source of good quality protein but the productivity is comparatively low i.e. $499 \mathrm{~kg} / \mathrm{ha}$ (Directorate of Economics and statistics, 2016). This is due to various abiotic and biotic stresses and lack of suitable genotypes/varieties. Abiotic stresses cause considerable loss in productivity of pulse crops. Among various stresses, low temperature is one of the most crucial signals affecting plant growth and even leading to death. Cold temperatures in the early growing season greatly affect its cultivation. Exposure of mungbean seedlings to $4{ }^{\circ} \mathrm{C}$ for 2 days resulted in irreversible cellular electrolyte leakage, but cold acclimation at $10^{\circ} \mathrm{C}$ reduced the damage (Chang et al., 2001). Exposure of plants to low temperature induces the over-production of reactive oxygen species (ROS) like superoxide radical $\left(\mathrm{O}_{2} \bullet-\right), \mathrm{H}_{2} \mathrm{O}_{2}$, and hydroxyl radical $\left(\mathrm{HO}^{-}\right)$in 
plant cells (Hung et al., 2005). ROS are highly reactive to membrane lipids, protein, and DNA and are believed to be one of the major contributing factors to chilling injuries (CIs) and to cause rapid cellular damage. When plants are exposed to low temperature, electron-transport chains tend to form $\mathrm{O}_{2} \bullet-$, which dismutase to form $\mathrm{H}_{2} \mathrm{O}_{2}$. In the chloroplast, low temperature limits the dark reactions, thus limiting the supply of $\mathrm{NADP}^{+}$ and favoring reduction of $\mathrm{O}_{2}$ by photo-system II. Therefore, exposure to low temperature in combination with high light intensity leads to more serious damage in plants (Allen and Ort, 2001). Tropical and subtropical plants exhibit marked physiological and biochemical dysfunctions commonly referred to as chilling injury when they are exposed to temperature below $10^{\circ} \mathrm{C}$ to $12^{\circ} \mathrm{C}$ (Graham and Patterson, 1982). These dysfunctions include alteration in membrane structure and lipid composition (Lyons et al., 1979) metabolic modifications (Levitt, 1980), changes in protein content and enzyme activities, phosphorylation of thylakoid proteins (Bannett, 1991), redistribution of intracellular Calcium ions (Bush, 1995), cellular leakage of electrolytes and amino acids, and a diversion of electron flow to alternate pathways (Leopold and Musgrave, 1979). However, there is still a paucity of information on the effects of cold acclimation and root temperature on chilling injury as well as lack of suitable cold tolerance genotypes in greengram.

Among the biotic constraints, yellow mosaic disease (YMD) caused by the mungbean yellow mosaic virus is the major threat for huge economic losses in the Indian subcontinent (Nene, 1973). The disease is caused by white fly (Bemicia tabaci) transmitted begomo gemini viruses with bipartite genomes (Varma and Malathi, 2003). Begomoviruses are a group of plant viruses containing single-stranded circular DNA encapsidated in geminate particles (Khattak et al., 2000; Karthikeyan et al., 2004). Greengram plants infected with yellow mosaic disease generally show yellowing or chlorosis of leaves followed by necrosis, shortening of internodes, and severe stunting of plants with no yield or few flowers and deformed pods produced with small, immature and shriveled seeds (Akhtar et al., 2009). This disease causes 10-100 percent yield losses depending on the crop stage at which the plants being infected (Bashir et al., 2006; Pandey et al., 2009). The choice of parents for crosses is a crucial factor determining success of recombination breeding for yield in autogamous crops. Thus the present study was undertaken to screen out suitable high yielding genotypes of greengram having cold tolerance as well as resistance to MYMV.

\section{Materials and Methods}

Twenty one greengram genotypes were selected from 57 newly developed lines on the basis of yield performance under field conditions. On next year these twenty one superior genotypes were evaluated for their yield performance and reaction to cold and MYMV along with nine released varieties as control/check. Satya et al., (2011) reported that chilling stress is one of the major abiotic stresses for greengram during germination stage as during germination starch and protein reserves in greengram cotyledons are degraded, which is hampered by chilling stress. The tolerant genotypes were more capable of channeling the cotyledon reserves for seedling growth, resulting in higher seedling vigor.

Thus response to cold exposure was studied under controlled condition in the S.K. Sinha molecular breeding laboratory by exposing these selected genotypes along with the check varieties to $15^{\circ} \mathrm{C}$ temperature at 10 days, 20 days and 30 days stage of growth to study their 
viability. Four set of these thirty genotypes were sown in field on 27.11.2014. Germination of each genotype was observed after three days of sowing. After germination the first replication was taken into incubator on 10.12.14. Number of plants of each genotype that wilted everyday and days to survival under cold stress was recorded. After recording the observations in incubator condition, the genotypes were exposed to field condition and their survival in field condition was recorded every day. Then total survival day (incubator and field) was calculated for screening of genotype resistance to cold. Second and third set of replication was taken into incubator on 20.12.14 and 30.12.14 respectively and observations were taken in the similar way to first set of replication and then field exposure was done. In field condition, all the three set of treatments were compared with the fourth set (control) and observations were taken every day for survival. Disease score was recorded at maturity stage by counting number of infected plants in each line and the per cent disease incidence was calculated. The disease intensity was scored adopting the following 1-9 score (Singh et.al., 1988) (Table 1). On maturity 100 random plants of each entry selected and harvested separately from which the average plant yield of each entry calculated.

\section{Results and Discussion}

The thirty genotypes (Table 2), when exposed to low temperature, at 10 days seedling stage, the maximum days of survival was observed in case of OBGG-2013-52 (29 days) followed by OBGG-2013-53 (25 days), OBGG-201322 (24 days), OBGG-2013-9 and OBGG2013-14(22 days). The genotypes which died in incubator were OBGG-2013-2(4 days), OBGG-2013-7 (2days), OBGG-2013-12 (7 days), OBGG-2013-15 (4 days), OBGG2013-16 (6days) and OBGG-2013-23 (5 days) for which these genotypes could not be exposed to field condition. The genotype OBGG-2013-7 was found to be very susceptible to cold at 10 days- old seedling stage. When 20 days old seedling were exposed to cold, the maximum days of survival was found in case of OBGG-2013-52 (35 days) which is more than when it is exposed at 10 days old seedling followed by OBGG-2013-23 (24 days,) OBGG-2013-12, OBGG-2013-16 (23 days), OBGG-2013-51, OBGG-2013-39(22 days), OBGG-2013-10 (22 days) and OBGG-2013-8(22 days).

Twenty days old seedling which died in the incubator were OBGG-2013-7 (4 days), OBGG-2013-7 (5 days), OBGG-2013-7-2 (6 days), OBGG-2013-46 (6 days), OBGG2013-49 (6 days), OBGG-2013-3 (7 days), OBGG-2013-5 (7 days), OBGG-2013-20 (7 days) and OBGG-2013-44 (7 days), OBGG2013-11 (8 days), OBGG-2013-22 (8 days) and OBGG-2013-53 (8 days). Considering both the yield and tolerance to cold at the 2 stages of growth of the crop, It was observed that the genotype which showed maximum survival to cold at both the stages(10 days and 20 days) i.e. OBGG-2013-52 is a low yielder (1.863 g/plant). The genotype OBGG-201334 (5.55g/plant) whose yield was highest among all genotypes showed medium tolerance to cold whereas the genotype OBGG-2013-7 (4.15g/plant) was though a high yielder but very sensitive to cold at all stages. Some genotypes were average yielders and also showed medium tolerance to cold like OBGG-2013-8 (3.83 g/plant), OBGG2013-10 (3.53g/plant). OBGG-2013-11 (4.54 $\mathrm{g} /$ plant) and OBGG-2013-20 (4.75g/plant) were high yielder plants but sensitive to cold at 20 days old seedling stage. The genotypes OBGG-2013-15 (4.37g /plant), OBGG-2013$16(3.89 \mathrm{~g} /$ plant $)$ were high yielder but sensitive to cold at early stage. High yielder but moderate sensitivity to cold was found in the genotypes OBGG-2013-24(4.36 g/plant) and OBGG-2013-4 (4.48 g/plant). 
Table.1 Rating scale for MYMV (Singh et al., 1988)

\begin{tabular}{|l|l|l|}
\hline Scale & Plants/foliage affected & Reaction \\
\hline 1 & $0.1-5.0 \%$ & Resistant (R) \\
\hline 3 & $5.1-10.0 \%$ & Moderately Resistant (MR) \\
\hline 5 & $10.1-25.0 \%$ & Moderately susceptible (MS) \\
\hline 7 & $25.1-50.0 \%$ & Susceptible (S) \\
\hline 9 & $50.1-100 \%$ & Highly susceptible (HS) \\
\hline
\end{tabular}

Table.2 Mean performance of greengram genotypes for yield attributing characters

\begin{tabular}{|c|l|c|c|c|c|c|c|}
\hline Genotypes & $\begin{array}{c}\text { Clusters/ } \\
\text { plant }\end{array}$ & $\begin{array}{c}\text { Pods / } \\
\text { Cluster }\end{array}$ & $\begin{array}{c}\text { Pod } \\
\text { length }\end{array}$ & $\begin{array}{c}\text { Seeds / } \\
\text { pod }\end{array}$ & $\begin{array}{c}\text { 100 seed } \\
\text { weight }\end{array}$ & $\begin{array}{c}\text { Yield/ } \\
\text { plant }\end{array}$ \\
\hline 1 & OBGG-2013-2 & 4.00 & 8.56 & 4.88 & 6.76 & 3.77 & 2.73 \\
\hline 2 & OBGG-2013-3 & 3.00 & 7.76 & 6.93 & 6.80 & 3.00 & 2.10 \\
\hline 3 & OBGG-2013-5 & 3.00 & 6.50 & 6.10 & 6.33 & 3.45 & 1.42 \\
\hline 4 & OBGG-2013-7 & 4.80 & 11.46 & 5.84 & 8.00 & 4.37 & 4.15 \\
\hline 5 & OBGG-2013-8 & 3.23 & 13.76 & 6.10 & 6.76 & 4.04 & 3.83 \\
\hline 6 & OBGG-2013-9 & 4.41 & 11.31 & 6.62 & 6.50 & 2.87 & 2.07 \\
\hline 7 & OBGG-2013-10 & 4.30 & 9.00 & 6.80 & 7.16 & 3.70 & 3.53 \\
\hline 8 & OBGG-2013-11 & 5.03 & 15.53 & 5.64 & 6.90 & 3.90 & 4.54 \\
\hline 9 & OBGG-2013-12 & 4.70 & 15.20 & 6.44 & 6.36 & 3.73 & 3.56 \\
\hline 10 & OBGG-2013-14 & 2.60 & 10.00 & 5.98 & 5.83 & 3.54 & 2.09 \\
\hline 11 & OBGG-2013-15 & 4.16 & 15.53 & 6.07 & 7.26 & 3.82 & 4.37 \\
\hline 12 & OBGG-2013-16 & 5.60 & 14.43 & 6.07 & 7.20 & 3.88 & 3.89 \\
\hline 13 & OBGG-2013-20 & 4.33 & 18.66 & 6.76 & 7.13 & 3.54 & 4.75 \\
\hline 14 & OBGG-2013-21 & 4.00 & 13.00 & 6.76 & 6.80 & 3.83 & 3.45 \\
\hline 15 & OBGG-2013-22 & 3.90 & 11.20 & 6.10 & 6.56 & 2.75 & 2.22 \\
\hline 16 & OBGG-2013-23 & 4.33 & 12.63 & 6.07 & 7.56 & 3.36 & 2.94 \\
\hline 17 & OBGG-2013-24 & 3.60 & 20.66 & 6.63 & 6.33 & 3.48 & 4.36 \\
\hline 18 & OBGG-2013-34 & 3.23 & 6.60 & 11.0 & 10.00 & 4.94 & 5.55 \\
\hline 19 & OBGG-2013-39 & 3.86 & 11.43 & 5.94 & 6.96 & 4.21 & 2.77 \\
\hline 20 & OBGG-2013-40 & 3.96 & 11.10 & 6.11 & 5.93 & 3.74 & 2.32 \\
\hline 21 & OBGG-2013-42 & 4.70 & 14.66 & 5.83 & 7.50 & 3.64 & 4.02 \\
\hline 22 & IPM-02-03(C) & 2.47 & 11.96 & 5.75 & 5.46 & 4.23 & 2.86 \\
\hline 23 & OUM-11-5(C) & 3.41 & 10.81 & 6.17 & 6.50 & 3.10 & 2.75 \\
\hline 24 & Tarm-1 (C) & 6.60 & 27.66 & 6.10 & 4.80 & 4.40 & 4.48 \\
\hline 25 & Dhauli (C) & 2.96 & 8.00 & 6.09 & 6.26 & 3.73 & 1.65 \\
\hline 26 & Sujata (C) & 2.70 & 6.23 & 5.25 & 6.16 & 4.24 & 2.08 \\
\hline 27 & Pusa-Visal (C) & 3.33 & 12.33 & 5.50 & 5.93 & 3.47 & 2.48 \\
\hline 28 & LGG-407 (C) & 3.00 & 9.33 & 5.86 & 5.26 & 3.29 & 1.86 \\
\hline 29 & LGG-460 (C) & 4.16 & 12.60 & 5.72 & 6.06 & 4.54 & 3.49 \\
\hline 30 & PUSA-9072(C) & 4.16 & 14.61 & 6.20 & 6.83 & 3.35 & 3.41 \\
\hline & MEAN & 3.91 & 12.42 & 6.245 & 6.667 & 3.904 & 3.193 \\
\hline & SE & 0.52 & 1.304 & 0.328 & 0.477 & 0.228 & 0.350 \\
\hline & CD & 1.048 & 2.611 & 0.656 & 0.955 & 0.456 & 0.701 \\
\hline
\end{tabular}

(C) $=$ control/check 
Table.3 Reaction of different greengram genotypes to cold stress and MYMV

\begin{tabular}{|c|c|c|c|c|c|c|c|c|c|c|}
\hline \multirow{2}{*}{$\begin{array}{c}\text { Sl } \\
\text { No. }\end{array}$} & \multirow[b]{2}{*}{ Genotypes } & \multicolumn{3}{|c|}{10 days old seedling } & \multicolumn{3}{|c|}{20 days old seedling } & \multirow{2}{*}{$\begin{array}{l}\text { Yield } \\
\text { (gm } \\
\text { /plant) }\end{array}$} & \multirow[b]{2}{*}{$\begin{array}{l}\text { Disease } \\
\text { Score }\end{array}$} & \multirow[b]{2}{*}{$\begin{array}{l}\text { Disease } \\
\text { Reaction }\end{array}$} \\
\hline & & $\begin{array}{l}\text { Survival in } \\
\text { incubator } \\
\text { (in days) }\end{array}$ & $\begin{array}{c}\text { Survival } \\
\text { in field } \\
\text { (in days) }\end{array}$ & $\begin{array}{c}\text { Total } \\
\text { survival } \\
\text { (in days) }\end{array}$ & $\begin{array}{l}\text { Survival in } \\
\text { incubator } \\
\text { (in days) }\end{array}$ & $\begin{array}{l}\text { Survival } \\
\text { in field(in } \\
\text { days) }\end{array}$ & $\begin{array}{c}\text { Total } \\
\text { survival } \\
\text { (in days) }\end{array}$ & & & \\
\hline 1 & OBGG-2013-2 & 4 & - & 4 & 6 & - & 6 & 2.73 & 5 & MS \\
\hline 2 & OBGG-2013-3 & 10 & 9 & 13 & 7 & - & 7 & 2.10 & 9 & $\mathrm{HS}$ \\
\hline 3 & OBGG-2013-5 & 10 & 10 & 20 & 7 & - & 7 & 1.40 & 9 & $\mathrm{HS}$ \\
\hline 4 & OBGG-2013-7 & 2 & - & 2 & 4 & - & 4 & 4.15 & 9 & $\mathrm{HS}$ \\
\hline 5 & OBGG-2013-8 & 10 & 8 & 18 & 10 & 12 & 22 & 3.83 & 3 & MR \\
\hline 6 & OBGG-2013-9 & 10 & 12 & 22 & 10 & 11 & 21 & 2.07 & 5 & MS \\
\hline 7 & OBGG-2013-10 & 10 & 8 & 18 & 10 & 12 & 22 & 3.53 & 5 & MS \\
\hline 8 & OBGG-2013-11 & 10 & 7 & 17 & 8 & - & 8 & 4.54 & 3 & MR \\
\hline 9 & OBGG-2013-12 & 7 & - & 7 & 10 & 13 & 23 & 3.56 & 3 & MR \\
\hline 10 & OBGG-2013-14 & 10 & 12 & 22 & 10 & 11 & 21 & 2.09 & 5 & MS \\
\hline 11 & OBGG-2013-15 & 4 & - & 4 & 10 & 9 & 19 & 4.37 & 9 & $\mathrm{HS}$ \\
\hline 12 & OBGG-2013-16 & 6 & - & 6 & 10 & 13 & 23 & 3.89 & 1 & $\mathrm{R}$ \\
\hline 13 & OBGG-2013-20 & 10 & 4 & 14 & 7 & - & 7 & 4.75 & 1 & $\mathrm{R}$ \\
\hline 14 & OBGG-2013-21 & 10 & 7 & 17 & 5 & - & 5 & 3.45 & 1 & $\mathrm{R}$ \\
\hline 15 & OBGG-2013-22 & 10 & 14 & 24 & 8 & - & 8 & 2.22 & 7 & $\mathrm{~S}$ \\
\hline 16 & OBGG-2013-23 & 5 & - & 5 & 10 & 14 & 24 & 2.94 & 9 & $\mathrm{HS}$ \\
\hline 17 & OBGG-2013-24 & 10 & 4 & 14 & 10 & 7 & 17 & 4.36 & 7 & $\mathrm{~S}$ \\
\hline 18 & OBGG-2013-34 & 10 & 9 & 19 & 10 & 7 & 17 & 5.55 & 5 & MS \\
\hline 19 & OBGG-2013-39 & 10 & 6 & 16 & 10 & 12 & 22 & 2.77 & 3 & MR \\
\hline 20 & OBGG-2013-40 & 10 & 11 & 21 & 10 & 8 & 18 & 2.32 & 5 & MS \\
\hline 21 & OBGG-2013-42 & 10 & 6 & 16 & 10 & 4 & 14 & 4.02 & 7 & $\mathrm{~S}$ \\
\hline 22 & IPM-02-03 (C) & 10 & 8 & 18 & 7 & - & 7 & 2.86 & 7 & $\mathrm{~S}$ \\
\hline 23 & OUM-11-5(C) & 10 & 5 & 15 & 6 & - & 6 & 2.75 & 7 & $\mathrm{~S}$ \\
\hline 24 & Tarm-1(C) & 10 & 2 & 12 & 10 & 4 & 14 & 4.48 & 5 & MS \\
\hline 25 & Dhauli (C) & 10 & 5 & 15 & 10 & 6 & 16 & 1.65 & 7 & $\mathrm{~S}$ \\
\hline 26 & Sujata $(\mathrm{C})$ & 10 & 6 & 16 & 6 & - & 6 & 2.08 & 5 & MS \\
\hline 27 & Pusa-Visal(C) & 10 & 8 & 18 & 10 & 12 & 22 & 2.48 & 5 & MS \\
\hline 28 & LGG-407(C) & 10 & 19 & 29 & 10 & 15 & 25 & 1.86 & 5 & MS \\
\hline 29 & LGG-460(C) & 10 & 15 & 25 & 8 & - & 8 & 3.49 & 7 & $\mathrm{~S}$ \\
\hline 30 & PUSA-9072(C) & 10 & 10 & 20 & 9 & - & 9 & 3.41 & 5 & MS \\
\hline
\end{tabular}


Basing on the average seed yield per plant, it was observed that three lines i.e., OBGG 2013-34, OBGG 2013-20 and OBGG 201311 were found superior than the best check (TARM-1) however the best average seed yielding line (OBGG 2013-34) is moderately susceptible to YMD (Table 3) thus needs further improvement by hybridization with a suitable MYMV resistant varieties. The genotypes OBGG-2013-16, OBGG-2013-20 and OBGG-2013-21 were showed resistant reaction to YMD in field condition. The OBGG 2013-20 can be used as MYMV donor due to its high yielding line along with MYMV resistance gene or can be released as varieties after further yield improvement by proper plant selection.

The genotype OBGG-2013-34 was the highest yielder genotype having medium tolerance to cold with moderate susceptibility reaction to MYMV and produced 23\% more than the best check variety (TARM-1). OBGG-2013-20 and OBGG-2013-11 have showed resistant reaction and moderate resistant respectively to YMD in field condition but both are lack of cold tolerance ability. Thus recombination breeding between OBGG-2013-34 and OBGG-2013-20 or OBGG-2013-11 was expected to produce superior genotype combining gene for cold tolerance and MYMV resistance with higher yield potential.

\section{References}

Akhtar, K.P., Kitsanachandee, R., Srinives, P., Abbas, G., Asghar, M.J., Shah, T.M., Atta, B.M., Chatchawankanphanich, O., Sarwar, G., Ahmad, M. and Sarwar, N. 2009. Field evaluation of mungbean recombinant inbred lines against mungbean yellow mosaic disease using new disease scale in Thailand. Plant Pathol. J., 25: 422-428.

Allen, D.J. and Ort, D.R. 2001. Impacts of chilling temperatures on photosynthesis in warm-climate plants, Trends Plant Sci., 6(1): 36-42.

Bannett, J.1991. Protein phosphorylation in green plant chloroplast, Plant Mol. Bio., 42:281-311.

Bashir, M., Jamali, A.R. and Ahmed, Z. 2006. Genetic resistance in mungbean and mashbean germplasm against mungbean yellow mosaic begomovirus. Mycopath., 4(2): 1-4.

Bush, D. C. 1995. Calcium regulation in plant cells and its role in signalling, Ann.Rev. Plant Physiol. Plant Mol. Biol. 46: 95122.

Chang, M.Y., Chen, S. L. Lee, C.F. and Chen, Y.M. 2001. Cold-acclimation and root temperature protection from chilling injury in chilling-sensitive mungbean (Vigna radiata L.) seedlings Bot. Bull. Acad. Sin. 2001. 42: 53-60

Directorate of Economics and statistics (DES), 2016. //eands.dacnet.nic.in

Graham, D. and Patterson B.D. 1982. Response of plant to low, non-freezing temperatures Proteins, metabolism and aulomation. Annual Review Plant Physiology, 33:347-372.

Hung, S.H., Yu, C.W., and Lin, C.H. 2005. Hydrogen peroxide functions as a stress signal in plants. Bot. Bull. Acad. Sin. 4(6): 1-10.

Karthikeyan, A.S., Vanitharani, R., Balaji, V., Anuradha, S., Thillaichidambaram, P., Shivaprasad, P.V., Parameswari, C., Balamani, V., Saminathan, M. and Veluthambi, K. 2004. Analysis of an isolate of mungbean yellow mosaic virus (MYMV) with a highly variable DNA B component. Arch Virol., 149: 1643-1652.

Khattak, G.S.S., Haq, M.A., Ashraf, M. and Elahi, T. 2000. Genetics of mungbean yellow mosaic virus (MYMV) in mungbean (Vigna radiata (L.) Wilczek). J Genet Breed., 54: 237-243.

Leopold, A. C. and Musgrave, M.E. 1979. 
Respiratory changes with chilling injury of soybeans. Plant Physiol. 65: 702705 .

Levitt, J. 1939. The relation of cabbage hardiness to bund water, unfrozen water, and cell contraction when foozen, Plant Physiol, 14:93-112.

Lyons, J. M., Raison, J. K. and Steponkus, P. L. 1979. The plant membrane in response to low temperature an overview in low temperature stress in crop plants, Lyons, J.M., Graham, D., Rsison, J.K. (eds). Academic press, New York: 1-24.

Nene, Y.L. 1973. Viral diseases of some warm weather pulse crops in India. Plant Dis Rep., 57: 463-467.

Pandey, S., Sharma, M., Kumari, S., Gaur, P.M,, Chen, W., Kaur, L., Macleod, W., Basandrai, A.K., Basandrai, D., Bakr, A., Sandhu, J.S., Tripathi, H.S. and Gowda, C.L.L. 2009. Integrated foliar diseases management of legumes. In: Grain Legumes: Genetic improvement,
Management and Trade, Eds. By Masood Ali et al., pp.143-161. Indian Society of Pulses Research and Development, Indian Institute of Pulses Research, Kanpur, India.

Satya P, Saha A and Bhattacharya PM. 2011. Tolerance to chilling stress in germinating mungbean (Vigna radiata L. Wilczek) is associated with increased phenolics and peroxidase activity, Genetics and Plant Physiology, 1 (34):139-149

Singh, G., Kapoor, S. and Singh, K. 1988. Multiple disease resistance in mungbean with special emphasis on mungbean yellow mosaic virus. In S. Shanmugasundran (ed.) Proc. Second International mungbean symposium, 1620 Nov.1987, Bangkok. pp 290-296.

Varma, A. and Malathi, V.G. 2003. Emerging Gemini virus problems: a serious threat to crop production. Annals of Appl. Biol., 142: 145-164.

\section{How to cite this article:}

Kabi, M., T.R. Das and Baisakh, B. 2017. Screening of Superior Genotypes for Cold Tolerance and MYMV Resistance in Greengram (Vigna radiata). Int.J.Curr.Microbiol.App.Sci. 6(12): 2270-2276. doi: https://doi.org/10.20546/ijcmas.2017.612.262 